\title{
Identification, Isolation, and Promoter-Defined Separation of Mitotic Oligodendrocyte Progenitor Cells from the Adult Human Subcortical White Matter
}

\author{
Neeta Singh Roy, ${ }^{1,3}$ Su Wang, ${ }^{1,3}$ Catherine Harrison-Restelli, ${ }^{1}$ Abdellatif Benraiss, ${ }^{1}$ Richard A. R. Fraser, ${ }^{2}$ \\ Michel Gravel, ${ }^{4}$ Peter E. Braun, ${ }^{4}$ and Steven A. Goldman ${ }^{1}$ \\ Departments of ${ }^{1}$ Neurology and Neuroscience and ${ }^{2}$ Neurosurgery, Cornell University Medical College, New York, New \\ York 10021, 3Aitken Neuroscience Center, New York, New York 10021, and ${ }^{4}$ Department of Biochemistry, McGill \\ University, Montreal, Quebec, Canada H3A 2T5
}

Previous studies have suggested the persistence of oligodendrocyte progenitor cells in the adult mammalian subcortical white matter. To identify oligodendrocyte progenitors in the adult human subcortical white matter, we transfected dissociates of capsular white matter with plasmid DNA bearing the gene for green fluorescence protein (hGFP), placed under the control of the human early promoter (P2) for the oligodendrocytic protein cyclic nucleotide phosphodiesterase (P/hCNP2). Within $4 \mathrm{~d}$ after transfection with P/hCNP2:hGFP, a discrete population of small, bipolar cells were noted to express GFP. These cells were A2B5-positive $\left(\mathrm{A} 2 \mathrm{~B} 5^{+}\right)$, incorporated bromodeoxyuridine in vitro, and constituted $<0.5 \%$ of all cells. Using fluorescence-activated cell sorting (FACS), the P/hCNP2- driven $\mathrm{GFP}^{+}$cells were then isolated and enriched to nearpurity. In the weeks after FACS, most P/hCNP2:hGFP-sorted cells matured as morphologically and antigenically characteristic oligodendrocytes. Thus, the human subcortical white matter harbors mitotically competent progenitor cells, which give rise primarily to oligodendrocytes in vitro. By using fluorescent transgenes of GFP expressed under the control of an early oligodendrocytic promoter, these oligodendrocyte progenitor cells may be extracted and purified from adult human white matter in sufficient numbers for implantation and cell-based therapy.

Key words: regeneration; myelin; remyelination; cell sorting; stem cells; subependyma
Oligodendrocytes of the adult forebrain are primarily postmitotic. Nonetheless, persistent cycling oligodendrocyte progenitors (OPs) have been described in adult rodent subcortical white matter (Gensert and Goldman, 1996) and may provide a substrate for remyelination after demyelinating injury (Blakemore et al., 1996; Gensert and Goldman, 1997). In humans, the demonstration and identification of persistent subcortical progenitor cells have been more problematic. A pro-oligodendrocytic phenotype has been described in adult human subcortical white matter, although these postmitotic cells may have included mature oligodendrocytes recapitulating their developmental program after dissociation (Armstrong et al., 1992; Gogate et al., 1994). Rare examples of oligodendrocytes derived from mitotic division have been reported in human subcortical dissociates (Scolding et al., 1995), and candidate progenitors have been identified in histological sections on the basis of PDGF $\alpha$ receptor expression (Scolding et al., 1998). Nonetheless, the identification and isolation of viable mitotic oligodendrocyte progenitors from the adult human brain has proven an elusive goal. Indeed, not only have mitotically competent adult human OPs not been preparable in

Received April 19, 1999; revised July 30, 1999; accepted Aug. 27, 1999.

This work was supported by the National Multiple Sclerosis Society, the G. Harold and Leila Y. Mathers Charitable Foundation, the Human Frontiers Scientific Program, the Aitken Charitable Trust, and National Institutes of Health Grants R01NS29813 and R01NS33106. We thank Dr. Arturo Alvarez-Buylla for sharing with us his parenchymal dissociation protocols.

Drs. Roy and Wang contributed equally to this work.

Correspondence should be addressed to Dr. Steven A. Goldman, Department of Neurology and Neuroscience, Cornell University Medical Center, 1300 York Avenue, Room E607, New York, NY 10021. E-mail: sgoldm@mail.med.cornell.edu. Copyright @ 1999 Society for Neuroscience 0270-6474/99/199986-10\$05.00/0 the numbers or purity required for their characterization or functional engraftment, but their very existence in humans has been unclear (Scolding, 1997, 1998).

To establish the existence and relative incidence of oligodendrocyte progenitors in the adult human white matter, we therefore designed a new strategy for the isolation and enrichment of native oligodendrocyte precursors from adult brain tissue. For this purpose, we capitalized on a strategy initially developed for the identification of neuronal precursor cells in which cultured forebrain dissociates were transfected with the gene for green fluorescent protein (hGFP) (Chalfie et al., 1994; Levy et al., 1996), regulated by the early neuronal promoter for T $\alpha 1$ tubulin (Gloster et al., 1994). This approach permitted the recognition of live, fluorescent neuronal progenitor cells in mixed cell culture. Fluorescence-activated cell sorting (FACS) then permitted the high-yield enrichment and relative purification of these progenitor cells (Goldman et al., 1997; Wang et al., 1998a).

In the present study, we extended this strategy to identify and purify oligodendrocyte progenitors from adult human subcortical white matter. To this end, we used FACS of subcortical cells transfected with hGFP placed under the control of the $5^{\prime}$ regulatory region of an early oligodendrocytic protein, specifically the early promoter (P2) for 2',3'-cyclic nucleotide $3^{\prime}$-phosphodiesterase (CNP; EC 3.1.4.37) (Vogel et al., 1988; Tsukada and Kurihara, 1992). CNP protein is one of the earliest known myelinassociated proteins to be synthesized in developing oligodendrocytes. It is expressed by newly generated cells of oligodendrocytic lineage, even within the ventricular zone, and appears to be expressed by their precursors as well, in both rodents and humans (Scherer et al., 1994; Yu et al., 1994; Grever et al., 1997; Peyron 


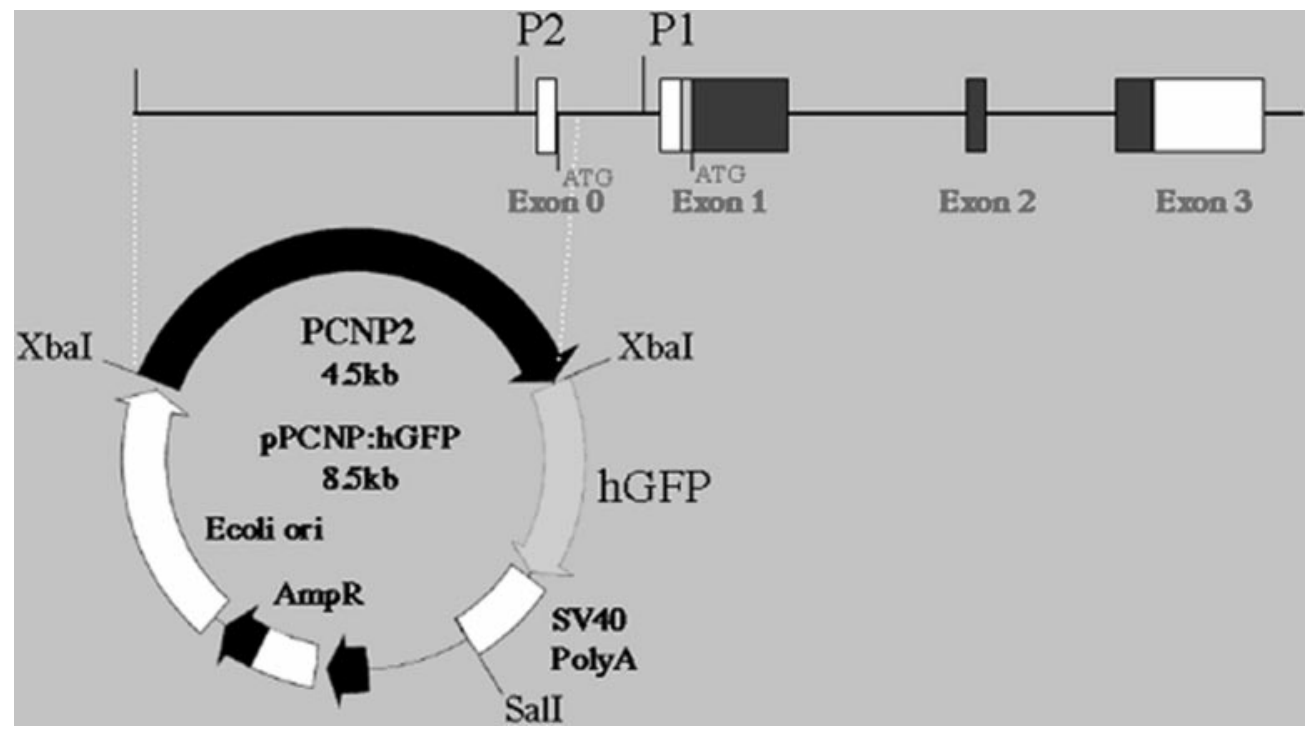

Figure 1. The human P/CNP2:hGFP vector. Humanized GFP (Levy et al., 1996), a mutant form of red-shifted GFP optimized for expression in human cells, was placed under the control of the human CNP2 promoter (P/hCNP2) (Gravel et al., 1996). To construct $\mathrm{P} / \mathrm{hCNP} 2$ :hGFP, an $X b a \mathrm{I}-X b a \mathrm{I}$ fragment encompassing exon 0 and part of intron 1 was isolated from the SK/ hgCNP plasmid, which contains the complete sequence of the human CNP gene (Gravel et al., 1996), and was then linked to the hGFP gene fused to the SV40 polyadenylation signal. et al., 1997; Chandross et al., 1999). Importantly, the 5' regulatory region of the CNP gene includes two distinct promoters, P2 and P1, which are associated with two distinct RNAs, and are sequentially activated at different developmental stages (Douglas et al., 1992; Douglas and Thompson, 1993; Monoh et al., 1993; Scherer et al., 1994) (Fig. 1). Only the CNP mRNA transcribed from the more upstream promoter, $\mathrm{P} 2$, is found in the fetal brain, suggesting that the $\mathrm{P} 2$ promoter $(\mathrm{P} / \mathrm{CNP} 2)$ directs expression to young oligodendrocytes and their precursors (O'Neill et al., 1997; Gravel et al., 1998). As a result, the CNP2 promoter was chosen for this study for its ability to target transgene expression to oligodendrocyte progenitors and their immature progeny in rodents. On this basis, we postulated that the human homolog of the CNP2 promoter, $\mathrm{P} / \mathrm{hCNP} 2$, would similarly target transgene expression to human oligodendrocyte progenitor cells.

We report here that the $\mathrm{P} / \mathrm{hCNP} 2$ has indeed allowed us to direct expression of a reporter gene to oligodendrocyte progenitor cells of the adult human brain and to thereby identify and isolate these cells. Plasmids of hGFP under the control of $\mathrm{P} / \mathrm{hCNP} 2$, transfected into dissociated subcortical cultures, identified a population of bipolar, primarily A2B5-immunopositive $\left(\mathrm{A} 2 \mathrm{~B} 5^{+}\right)$precursor cells. These cells typically incorporated the mitotic marker bromodeoxyuridine (BrdU) from the culture media and developed oligodendrocytic antigenic expression in vitro. Using FACS, we isolated these $\mathrm{P} / \mathrm{hCNP} 2: \mathrm{hGFP}^{+}$cells from surgically resected subcortical white matter and observed their development into mature, galactocerebroside ${ }^{+}$oligodendrocytes in the weeks thereafter. This strategy has allowed us to establish the existence of a distinct class of mitotically competent oligodendrocyte progenitors in the adult human white matter. In addition, P/hCNP2:hGFP-based FACS has enabled us to isolate and separate these cells, viably and in high-yield, and in numbers and purity sufficient to study their cell biology and suitability for engraftment.

Parts of this paper have been published previously in abstract form (Wang et al., 1998b).

\section{MATERIALS AND METHODS}

\section{Plasmid construction}

P/hCNP2:hGFP and P/hCNP2:lacZ. hGFP, a mutant form of GFP optimized for expression in human cells (Levy, 1996), was placed under the control of the human CNP2 promoter (Douglas et al., 1992; Monoh et al., 1993; Gravel et al., 1996). The human CNP gene had been isolated previously (Gravel et al., 1996) by screening a human fibroblast genomic library with a cDNA probe for rat CNP1 (Bernier et al., 1987). The human CNP gene was then subcloned into pBluescript, and the resultant plasmid was designated SK/hgCNP. This plasmid was digested with $B g l \mathrm{II}$ and $X h o I$ to delete much of the gene downstream of the promoter region. The remaining $B g l \mathrm{II}$ and $X h o \mathrm{I}$ ends were then filled in and blunt-end ligated, yielding plasmid SK/P1P2hCNP, in which both BglII and XhoI were regenerated. A 1123 bp XhoI-XhoI fragment containing SV40 $\mathrm{SD} / \mathrm{SA}-\mathrm{GFPh}-\mathrm{SV} 40$ poly $\left(\mathrm{A}^{+}\right)$was then excised from $\mathrm{pT} \alpha 1$ :hGFP (Wang et al., 1998) and subcloned into XhoI-digested SK/P1P2hCNP to generate the plasmid P/P1P2hCNP:hGFP. The orientation of the hGFP insert was then determined by restriction enzyme mapping.

To construct $\mathrm{P} / \mathrm{hCNP} 2$ :hGFP, the T $\alpha 1$ tubulin promoter region was excised from $\mathrm{pP} / \mathrm{T} \alpha 1$ hGFP using $\mathrm{XbaI}$ and replaced with the hCNP2 promoter obtained by digesting SK/hgCNP with $X b a \mathrm{I}$. The orientation of the P/hCNP2 insert was also determined by restriction enzyme mapping. Similarly, P/hCNP2:lacZ was constructed by removing the T $\alpha 1$ promoter from the T $\alpha 1$ :lacZ (Wang et al., 1998a) with $X b a \mathrm{I}$, and replacing it with the $X b a \mathrm{I}-X b a \mathrm{I}$ fragment containing the hCNP2 promoter. $\mathrm{P} / \mathrm{CMV}$ :hGFP was constructed as reported previously (Wang et al., 1998a).

\section{Adult human brain white matter dissociation and culture}

Adult human brain tissues, obtained freshly in the course of surgical resection, were collected directly into $\mathrm{Ca}^{2+} / \mathrm{Mg}^{2+}$-free HBSS. The white matter was dissected from the rest of the tissue, cut into pieces of $\sim 2 \mathrm{~mm}$ on edge, or $8 \mathrm{~mm}^{3}$, and rinsed twice with PIPES solution (in mM: 120 $\mathrm{NaCl}, 5 \mathrm{KCl}, 25$ glucose, and 20 PIPES). It was then digested in prewarmed papain-PIPES solution (11.4 U/ml papain; Worthington, Freehold, NJ) and DNase I (10 U/ml; Sigma, St. Louis, MO), on a rocking shaker for $1 \mathrm{hr}$ at $37^{\circ} \mathrm{C}$. The tissue was then collected by centrifuging at $200 \times g$ in an IEC Centra-4B centrifuge, resuspended in DMEM-F-12-N2 with DNase I $(10 \mathrm{U} / \mathrm{ml})$, and incubated for $15 \mathrm{~min}$ at $37^{\circ} \mathrm{C}$. The samples were again spun, and their pellets were recovered in $2 \mathrm{ml}$ of DMEM-F-12-N2. They were then dissociated by sequentially triturating for 20,10 , and 5 times, respectively, through three glass Pasteur pipettes fire polished to decreasing bore diameters. Undissociated tissue pieces were eliminated by passage through a fine $40 \mu \mathrm{m}$ mesh. The cells were collected and rinsed once with DMEM-F-12-N2 containing 20\% plasma-derived FBS (PD-FBS; Cocalico Biologicals, Reamstown, PA) to stop the enzymatic dissociation and then resuspended at $1 \times 10^{7}$ cells/ml in DMEM-F-12-N2 containing $10 \%$ FBS. The cell suspension was plated at $0.1 \mathrm{ml} /$ dish into $35 \mathrm{~mm}$ Falcon Primaria plates coated with laminin $\left(2 \mu \mathrm{g} / \mathrm{cm}^{2}\right)$ and incubated at $37^{\circ} \mathrm{C}$ in $5 \% \mathrm{CO}_{2}$. After $4 \mathrm{hr}$, an additional $0.7 \mathrm{ml}$ of DMEM-F-12-N2 with $2 \%$ PD-FBS was added into each plate. This medium was supplemented with PDGF AA (20 ng/ml; Sigma), FGF-2 (20 ng/ml; Sigma), NT-3 (20 ng/ml; Regeneron Pharmaceuticals, Tarrytown, NY), and BrdU $(10 \mu \mathrm{g} / \mathrm{ml})$. Cultures were transfected after 2-6 d in vitro (DIV). After transfection, the 
Figure 2. Adult human white matter harbors oligodendrocyte progenitors. Immunocytochemistry of white matter dissociates for a panel of cell type-selective antigens revealed a diverse representation of phenotypes before sorting. $A-C$, A typical bipolar cell, doublelabeled for A2B5 (red) and BrdU (yellow), fixed after 4 DIV. $D-F$, A cluster of postmitotic $\mathrm{O} 4{ }^{+}$cells $(D, E)$ and an overtly less mature BrdU-incorporating $\mathrm{O}^{+} / \mathrm{BrdU}^{+}$cell $(F)$, all fixed after 7 DIV. $G-I$, Representative examples of the diverse phenotypes present in the adult white matter. These included cells expressing CNP $(G)$, GFAP $(H)$, and TuJ1 $(I)$ immunoreactivities, which respectively identify oligodendrocytes, astrocytes, and neurons; each cell type was found in the proportion noted in Results. Scale bar, $40 \mu \mathrm{m}$.
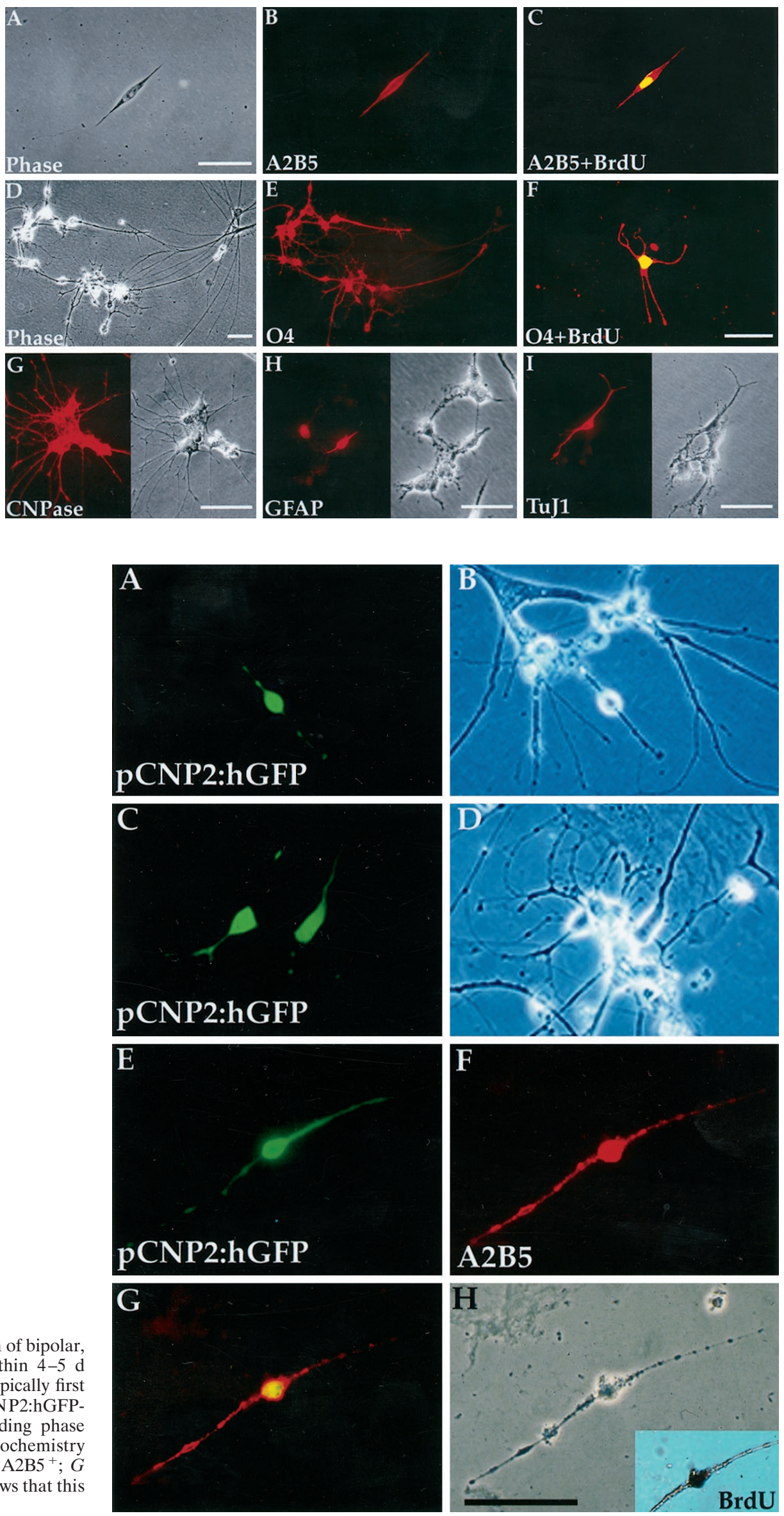

Figure 3. $\mathrm{P} / \mathrm{hCNP} 2 \mathrm{hGFP}$ identifies a population of bipolar, $\mathrm{A}^{2} 5^{+}$cells. GFP expression was observed within 4-5 d after transfection. The $\mathrm{P} / \mathrm{hCNP} 2: \mathrm{hGFP}^{+}$cells typically first appeared as small, bipolar cells. $A-F, \mathrm{P} / \mathrm{hCNP} 2$ :hGFPexpressing cells $(A, C, E)$ and their corresponding phase contrast micrographs $(B, D, H) . E, F$, Immunocytochemistry identified the P/hCNP2:hGFP ${ }^{+}$bipolar cells as $\mathrm{A} 2 \mathrm{~B} 5{ }^{+} ; G$ indicates double-labeling of the two. Inset in $H$ shows that this cell incorporated BrdU. Scale bar, $30 \mu \mathrm{m}$. 
cultures were switched to serum-free DMEM-F-12-N2, with maintained growth factor and BrdU supplementation until FACS.

\section{Transfection}

All plasmid constructs were introduced into the cultured cells by liposomal transfection, as described previously (Wang et al., 1998a). Briefly, 2-6 d after plating, each $35 \mathrm{~mm}$ dish received a mixture of $2 \mu \mathrm{g}$ of plasmid DNA and $10 \mu \mathrm{l}$ of lipofectin in OPTI-MEM (Life Technologies, Gaithersburg, MD). The cells were incubated at $37^{\circ} \mathrm{C}$ in $5 \% \mathrm{CO}_{2}-95 \%$ air for $6 \mathrm{hr}$. The transfections were terminated with DMEM-F-12-N2 containing $10 \%$ PD-FBS. After $2 \mathrm{hr}$, the cells were returned to serum free DMEM-F-12-N2 with PDGF AA, NT-3, and FGF2. Imaging for hGFP was first done $2 \mathrm{~d}$ after transfection and daily thereafter using an Olympus (Tokyo, Japan) IX70 epifluorescence microscope. The greatest number and proportion of $\mathrm{GFP}^{+}$cells were observed $6-7 \mathrm{~d}$ after transfection; cultures were therefore sorted at that time point.

\section{Flow cytometry and sorting}

Flow cytometry and sorting of $\mathrm{hGFP}^{+}$cells was performed on a FACS Vantage (Becton Dickinson, Cockeysville, MD). Cells $\left(5 \times 10^{6} / \mathrm{ml}\right)$ were analyzed by light forward and right angle (side) scatter and for GFP fluorescence through a $530 \pm 15 \mathrm{~nm}$ bandpass filter as they traversed the beam of an argon ion laser (488 nm, $100 \mathrm{~mW})$. P/hCNP2:lacZtransfected control cells were used to set the background fluorescence; a false positive rate of $0.02 \pm 0.05 \%$ was accepted to ensure an adequate yield. For the test samples transfected with $\mathrm{P} / \mathrm{hCNP} 2$ :hGFP, cells having fluorescence higher than background were sorted at 3000 cells/sec. Sorted cells were plated onto laminin-coated 24-well plates, into DMEM-F-12-N2 containing PDGF-AA, NT-3, and FGF2, each at 20 $\mathrm{ng} / \mathrm{ml}$. After $4 \mathrm{~d}$, some plates were fixed for immunocytochemistry, and the remainder was switched to DMEM-F-12-N2 containing 10\% PDFBS. After an additional 3 weeks in vitro, the sorted cells were stained for either CNP, O4, TuJ1, or glial fibrillary acidic protein (GFAP) immunoreactivities; each was double-stained for BrdU as well.

\section{Data analysis}

Experimental end points included the proportion of A2B5-, O4-, CNP-, GFA-, and TuJ1-immunoreactive cells in the total sorted population (all nominally $\mathrm{GFP}^{+}$after sorting), as a function of time after FACS. At each sampled time point, the respective proportions of $\mathrm{A} 2 \mathrm{~B} 5{ }^{+}, \mathrm{O} 4^{+}$, $\mathrm{CNP}^{+}, \mathrm{GFA}^{+}$, and $\beta \mathrm{III}-$ tubulin/TuJ1 ${ }^{+}$cells were compared with each other and with unsorted controls that were similarly dispersed but replated without sorting (after adjusting their cell densities to those of the post-FACS sorted pool). For each combination of treatment (sorted or unsorted), time point (4 $\mathrm{d}$ and 3-4 weeks after FACS), and immunolabel (A2B5, O4, CNP, TuJ1, and GFA), the number of stained and unstained cells were counted in 10 randomly chosen fields, in each of three triplicate cultures.

\section{Immunocytochemistry}

Cells were immunostained live for A2B5 or O4 (Bansal et al., 1989), or after fixation with $4 \%$ paraformaldehyde, for CNP, TuJ1, GFAP, or BrdU. Selected plates were also stained for CD68 or factor VIII, antigenic markers of microglial and endothelial cells, respectively (Kirschenbaum et al., 1994; Rafii et al., 1995). For A2B5 or O4 immunocytochemistry, plates were washed twice with DMEM-F-12-N2 and then blocked with DMEM-F-12-N2 containing 5\% normal goat serum (NGS) for 10 min at $4^{\circ} \mathrm{C}$. Monoclonal antibody (mAb) A2B5 (clone 105; American Type Culture Collection, Manassas, VA) was used as an undiluted culture supernatant, and mouse $\mathrm{mAb}$ O4 (Boehringer Mannheim, Indianapolis, IN) was used at 1:200. Both were applied in DMEM-F-12-N2 for $30 \mathrm{~min}$ at $4^{\circ} \mathrm{C}$. The plates were then washed with three changes of cold HBSS containing $1 \%$ NGS. The secondary antibody, Texas Redconjugated goat anti-mouse IgM was used at a dilution of 1:50 for $30 \mathrm{~min}$ at $4{ }^{\circ} \mathrm{C}$. The cells were then washed and fixed with cold $4 \%$ paraformaldehyde for $10 \mathrm{~min}$, washed, mounted in SlowFade, and observed using an Olympus IX70 equipped for epifluorescence. Immunocytochemistry for GFAP and TuJ1 was performed according to described methods (Wang et al., 1998a), as was that for TuJ1 and BrdU (Luskin et al., 1997), CD68 (Kirschenbaum et al., 1994), and factor VIII (Leventhal et al., 1999). Selected cultures were also stained for the more mature oligodendrocyte antigens $\mathrm{O} 1$ and galactocerebroside, as described previously (Bansal et al., 1989).

\section{RESULTS}

\section{Dissociates of adult human white matter harbored a pool of bipolar, A2B5 ${ }^{+}$cells}

To fully characterize the cell phenotypes resident in adult human white matter, papain dissociates of surgically resected frontal and temporal capsular white matter were obtained from eight patients. These included four males and four females, who ranged from 24 to 65 years old. Three patients had temporal lobe resections for medication refractory epilepsy; two were subjected to decompressive resection during or after extra-axial meningioma removal, two samples were taken during aneurysmal repair, and one was taken from the non-neoplastic approach to a histologically benign ganglioglioma. The monolayer cultures resulting from these white matter dissociations were stained after 5-7 DIV for either of two oligodendrocytic markers, which included the epitopes recognized by the A2B5 and O4 antibodies. Additional, matched cultures were stained after 14 DIV for A2B5, O4, or oligodendrocytic CNP protein, and for either neuronal ( $\beta$ IIItubulin) or astrocytic (GFAP) target antigens.

In the 14 DIV dissociates of subcortical white matter, $48.2 \pm$ $10.7 \%$ of the plated cells expressed the oligodendrocytic epitope recognized by mAb O4 ( $n=3$ patients, with a total of $935 \mathrm{O}^{+}$ cells among 2041 scored white matter cells; mean \pm SD) (Fig. 2). In matched plates, $49.9 \pm 4.9 \%$ were immunoreactive for oligodendrocytic CNP protein, and $7.3 \pm 3.2 \%$ expressed astrocytic GFAP. Double-labeling of selected plates revealed that the $4^{+}$ and $\mathrm{CNP}^{+}$pools were primarily overlapping, with a small proportion of $\mathrm{CNP}^{+} / \mathrm{O} 4$-negative $\left(\mathrm{O}^{-}\right)$cells. In contrast, the $\mathrm{GFA}^{+}$cells only rarely colabeled as $\mathrm{O}^{+}{ }^{+}$. A small proportion of $\mathrm{TuJ}^{+}$neurons $(5.2 \pm 2.2 \%)$ was also observed, as were factor VIII-immunoreactive endothelial cells $(11.7 \pm 8.9 \%)$ and CD68 $8^{+}$ microglia $(19.9 \pm 5.5 \%)$. Through $30 \mathrm{DIV}$, the proportions of oligodendrocytes and neurons in these cultures remained approximately stable, with $51.3 \pm 7.0 \% \mathrm{O}^{+}$cells and $6.0 \pm 2.1 \%$ $\mathrm{TuJ}^{+}$cells, respectively. In contrast, the proportion of GFAdefined astrocytes in these cultures increased from $7.3 \pm 3.2 \%$ at 14 DIV to $15.9 \pm 1.4 \%$ at 30 DIV ( $p<0.01$ by Student's $t$ test).

Notably, a distinct population of small bipolar cells, which expressed A2B5 but which otherwise expressed neither neuronal nor oligodendrocytic phenotypic markers, was observed; these constituted $1.8 \pm 0.4 \%$ ( $n=5$ patients) of all cultured white matter cells at $7 \mathrm{~d}$. However, these cells became scarcer with time in vitro by $30 \mathrm{DIV}$, and $\mathrm{A} 2 \mathrm{~B} 5{ }^{+}$cells constituted $<0.1 \%$ of the total cultured cell pool.

\section{The CNP2 promoter targeted GFP expression to a bipolar, $\mathrm{A} 2 \mathrm{~B}^{+}{ }^{+}$phenotype}

To identify either oligodendrocyte progenitor cells or their immature progeny, white matter dissociates were next transfected after 2-6 d with plasmids encoding P/hCNP2:hGFP. Within $4 \mathrm{~d}$ after transfection with $\mathrm{P} / \mathrm{hCNP} 2 \mathrm{hGFP}$, a small proportion of $\mathrm{GFP}^{+}$cells were noted. These were invariably small, bipolar cells and constituted $<1 \%$ of the total cell pool (Fig. 3). After an additional 4-7 d in vitro, the cultures were immunostained for one of three oligodendrocyte lineage markers, which included A2B5, $\mathrm{O} 4$, and CNP protein, or for either astrocytic GFAP or neuronal $\beta$ III-tubulin. At that point, the $\mathrm{GFP}^{+}$cells could generally be described as $\mathrm{A} 2 \mathrm{~B}^{+} / \mathrm{O} 4{ }^{ \pm} / \mathrm{GFAP}^{-} / \mathrm{TuJ} 1^{-} ; 62.5 \pm 8.8 \%$ of $\mathrm{P} / \mathrm{hCNP}: \mathrm{hGFP}^{+}$cells expressed A2B5-IR, $21.1 \pm 7.5 \%$ were $\mathrm{O}^{+}{ }^{+}$, and another $7.3 \pm 3.2 \%$ expressed astrocytic GFAP. None were recognized by $\mathrm{mAb} \mathrm{TuJ} 1$, which targets neuronal $\beta$ IIItubulin (Menezes and Luskin, 1994). Thus, within the first 7-10 
Figure 4. Culture, isolation, and enrichment of oligodendrocyte progenitors. Adult human subcortical white matter, derived from surgical samples of frontal and temporal lobe, was dissected and enzymatically dissociated using papain and DNase and then cultured and transfected with either $\mathrm{P} / \mathrm{hCNP} 2 \mathrm{hGFP}$ or control plasmids (P/ CMV:hGFP and P/hCNP2:lacZ).

\section{Identification and Enrichment of Oligodendrocyte Progenitor Cells from Adult Human Forebrain}

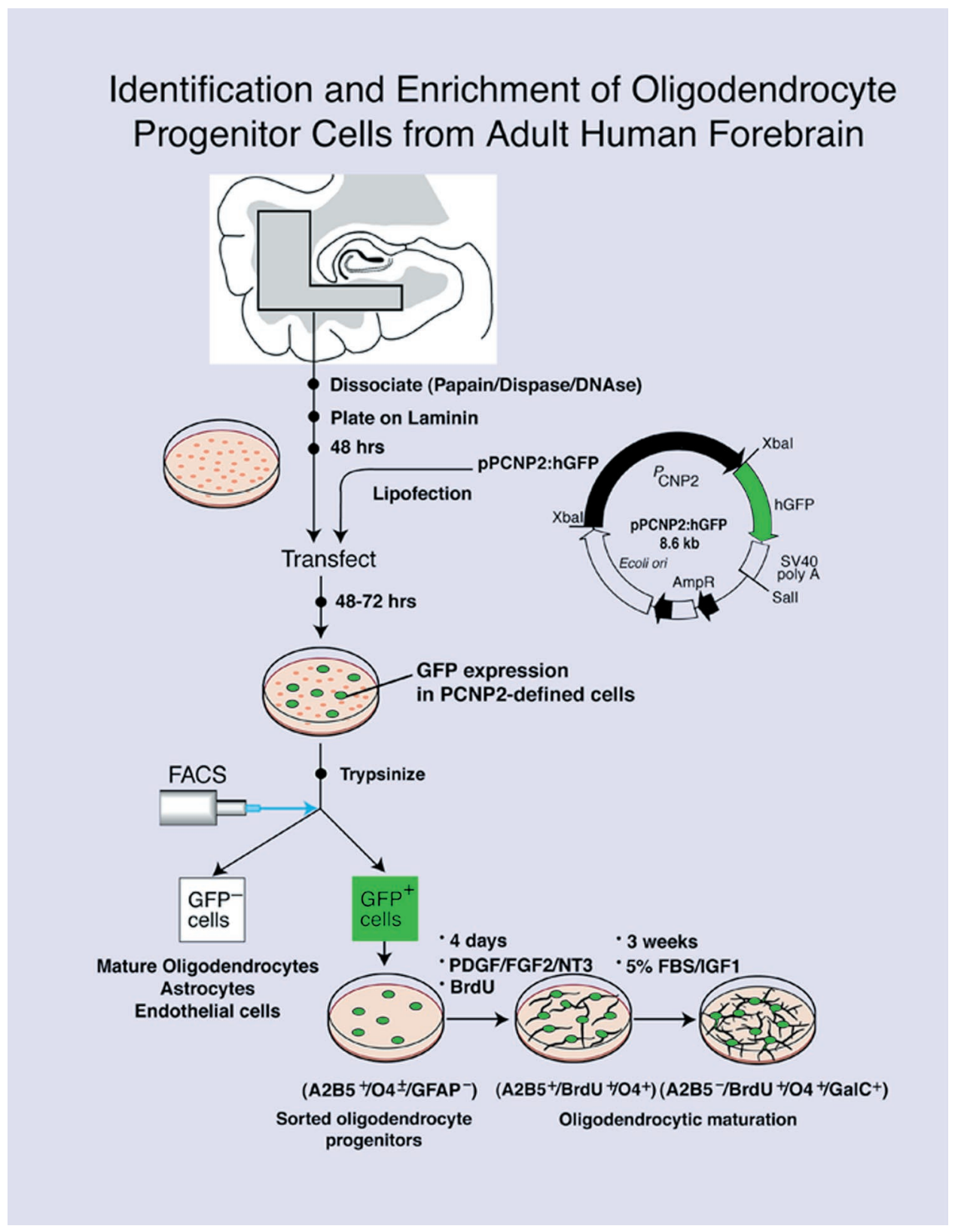

$\mathrm{d}$ in culture, $\mathrm{P} / \mathrm{hCNP}$ :hGFP selectively identified a population of bipolar, $\mathrm{A} 2 \mathrm{~B} 5{ }^{+}$cells. When followed over the weeks thereafter, most of these $\mathrm{P} / \mathrm{hCNP} 2 \mathrm{hGFP}^{+}$cells developed into oligodendrocytes, which could be recognized by their small, multipolar, heavily branching profiles. Indeed, by 4 weeks, most $\mathrm{P} / \mathrm{hCNP}$ :hGFP ${ }^{+}$cells expressed O4, whereas only rare cells $(<1 \%)$ continued to express A2B5 immunoreactivity.

\section{P/hCNP2:hGFP-identified cells were mitotic in vitro}

Among white matter dissociates continuously exposed to BrdU and transfected with $\mathrm{pP} / \mathrm{hCNP} 2$ :hGFP on day 4 in vitro, $55 \pm$ $14.8 \%$ of the resultant $\mathrm{P} / \mathrm{hCNP} 2: \mathrm{hGFP}^{+}$cells incorporated BrdU by day 7 ( $n=30$ plates, derived from three patients) (Fig. $3)$. Similarly, $43.1 \pm 9.1 \%(n=5$ plates $)$ of the A2B5 ${ }^{+}$cells in matched plates incorporated BrdU over the same time period. Morphologically, essentially all of these A2B5 ${ }^{+}$and BrdU ${ }^{+}$cells were bipolar at 1 week (Fig. 2). In contrast, the large majority of morphologically mature oligodendrocytes failed to incorporate
BrdU in vitro. Only $2.1 \pm 1.1 \%$ of $\mathrm{O}^{+}$cells labeled with BrdU to which they were exposed during the first week in culture, and these few $\mathrm{O}^{+}{ }^{+}$cells may have just arisen from $\mathrm{A} 2 \mathrm{~B} 5^{+}$forebears.

\section{P/hCNP2:hGFP-based FACS yielded a distinct pool of bipolar, A2B5 ${ }^{+}$progenitors}

Using sorting criteria intended for cell type purification, the $\mathrm{P} / \mathrm{hCNP} 2$-driven $\mathrm{GFP}^{+}$cells were then enriched and cultured separately (Fig. 4). Immediately after FACS, P/hCNP2:hGFPseparated cells primarily expressed A2B5-IR. Furthermore, the majority of these $\mathrm{A} 2 \mathrm{~B} 5^{+}$cells were found to have incorporated BrdU from their culture medium before FACS, indicating their mitogenesis in vitro (Fig. 5). Within the week after sorting and with concurrent transfer to higher serum media, most of the sorted cells developed O4 expression and lost A2B5-IR.

Notably, P/hCNP2:hGFP-separable cells were not rare. Among seven patients whose white matter dissociates were trans- 

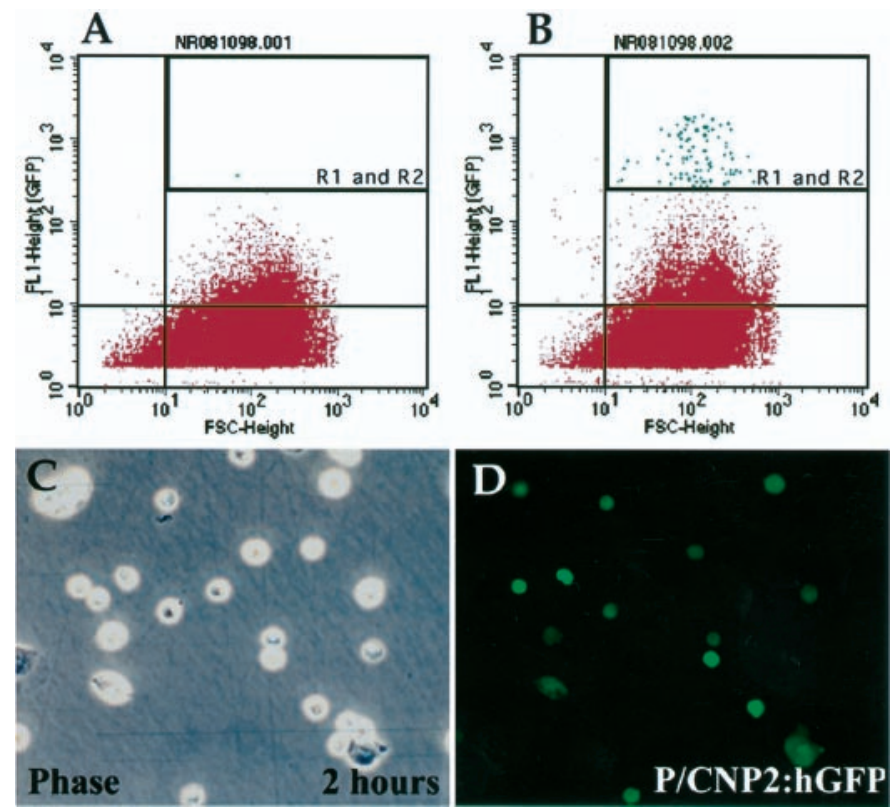

Figure 5. Isolation of $\mathrm{P} / \mathrm{hCNP} 2 \mathrm{hGFP}^{+}$cells by FACS. $A$ and $B$ shows a representative sort of a human white matter sample, derived from the frontal lobe of a 42-year-old woman during repair of an intracranial aneurysm. This plot shows 50,000 cells (sorting events) with their GFP fluorescence intensity (FL1), plotted against their forward scatter (FSC, a measure of cell size). $A$ indicates the plot obtained from a nonfluorescent P/hCNP2:lacZ-transfected control, whereas $B$ indicates the corresponding result from a matched culture transfected with $\mathrm{P} / \mathrm{hCNP} 2$ :hGFP. The boxed area $(R 1$ and $R 2)$ includes those $\mathrm{P} / \mathrm{hCNP}$ :hGFP ${ }^{+}$cells recognized and separated on the basis of their fluorescence emission. The many cells thereby recognized in the $\mathrm{P} / \mathrm{hCNP} 2$ :hGFP-transfected sample $(B)$ contrasts to the rare cells so identified in the nonfluorescent $\mathrm{P} / \mathrm{hCNP}$ :lacZtransfected control $(A) . C$ and $D$ show phase and fluorescence images of $\mathrm{GFP}^{+}$cells $2 \mathrm{hr}$ after sorting. Scale bar, $20 \mu \mathrm{m}$.

fected with $\mathrm{P} / \mathrm{hCNP} 2$ :hGFP, $0.59 \pm 0.1 \%$ of all subcortical cells expressed the transgene and could be separated on that basis. As a result, typically $>2000$ pCNP2: $\mathrm{hGFP}^{+}$cells $(2382 \pm 944)$ were obtained from sorts that averaged 352,000 gated cells (Fig. 6).

\section{Plasmid transfection favored transgene expression by mitotic targets}

The incidence of progenitor cells in the adult white matter may be estimated from the frequency of P/hCNP2-defined cells in these cultures, once the transfection efficiency of this cell population is known relative to the overall white matter cell population. In this regard, our net transfection efficiency, determined using P/CMV: hGFP, was $13.5 \pm 2.2 \%$ ( $n=3$ plates; 10 low-power fields of each were scored). This suggested that approximately one cell in eight was successfully transfected with the promoter-driven reporter. On this basis, we estimated that oligodendrocyte progenitor cells might comprise as many as $4 \%(0.59 \% \times 1 / 0.135=4.37 \%)$ of all cells in the subcortical white matter. However, this figure needs to be viewed cautiously, because it assumes that all cells in these cultures were transfected and expressed the plasmid vectors with equal efficiency, regardless of their phenotype or mitotic competence. To test this assumption, we exposed a sample of white matter cultures to BrdU, and 3 d later, transfected them with a plasmid of GFP regulated by the constitutively active cytomegalovirus (CMV) promoter (P/CMV:hGFP) $(n=3$ plates, with 15 fields from each scored). One week later, the cultures were fixed, and the relative proportions of mitotic $\left(\mathrm{BrdU}^{+}\right)$and postmitotic $\left(\mathrm{BrdU}^{-}\right) \mathrm{GFP}^{+}$transfectants were determined.
In keeping with the postmitotic nature of mature oligodendrocytes, only $16.1 \pm 1.2 \%$ of the cells in unsorted white matter cultures had incorporated BrdU by $10 \mathrm{~d}$ in vitro $(n=20$ fields; mean \pm SEM). In these same cultures, $9.4 \pm 1.0 \%$ of the cells expressed GFP placed under the control of the CMV promoter. Remarkably, however, $78.3 \pm 6.5 \%$ of these $\mathrm{GFP}^{+}$cells were $\mathrm{BrdU}^{+}$; this value was over fourfold greater than the BrdU labeling index of the total cell population $(p<0.01$ by Fisher's exact test). These data suggested that the transduction efficacy of dividing cells in these cultures was substantially higher than that of postmitotic cells. This in turn suggested that mature oligodendrocytes were either transduced with less efficiency or exhibited less efficient transgene expression than mitotically competent oligodendrocyte progenitor cells. As a result, although the $\mathrm{P} / \mathrm{CNP} 2$ promoter might have been expected to drive transgene expression in oligodendrocytes as well as their progenitor cells, the greater transfection efficiency of dividing cells would have restricted CNP2:hGFP expression to mitotic cells in the oligodendroglial lineage, resulting in selective GFP expression by the oligodendrocyte progenitor pool. Thus, the enhanced transfection and expression of episomal plasmids in dividing cells, combined with the restriction of $\mathrm{P} / \mathrm{CNP} 2$ transcriptional activation to oligodendrocyte progenitors and their daughters, appeared to collaborate to account for the selective expression of $\mathrm{P} / \mathrm{CNP} 2$ : hGFP by these adult human oligodendrocyte progenitor cells.

\section{P/hCNP2:hGFP ${ }^{+}$-sorted cells matured primarily, but not exclusively, into oligodendrocytes}

Whether mitotic or postmitotic when transfected, the majority of $\mathrm{P} / \mathrm{hCNP} 2$-sorted cells developed and matured as oligodendrocytes. By 3 weeks after FACS, $74.1 \pm 7.7 \%$ of these cells expressed oligodendrocytic CNP protein; a matched sample of sorted cells stained after 3 weeks in vitro for $\mathrm{O} 4$ yielded $66.3 \pm$ $6.8 \%$ O4-IR cells, most of which colabeled for the more mature marker galactocerebroside (Fig. 7). Nonetheless, concurrent development of nonoligodendrocytic phenotypes was also noted after FACS purification, albeit at lower frequency than oligodendrocytes; immediately after sorting, $6.5 \pm 5.4 \%$ of the sorted cells expressed GFAP, and $11.0 \pm 4.6 \%$ were $\mathrm{GFAP}^{+}$by 3 weeks in vitro. These were not simply false positive contaminants because most were observed to express $\mathrm{P} / \mathrm{hCNP} 2$ :hGFP fluorescence. No

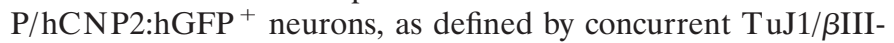
tubulin-IR, were observed immediately before FACS. Surprisingly however, $7.5 \pm 4.4 \%$ of $\mathrm{P} / \mathrm{hCNP} 2$ :hGFP-sorted cells were noted to mature into $\beta \mathrm{III}$-tubulin $/ \mathrm{TuJ} 1^{+}$neurons in the week after sorting. These $\mathrm{TuJ} 1^{+}$cells were similarly confirmed visually as expressing $\mathrm{P} / \mathrm{hCNP}$ :hGFP (Fig. 8). Importantly, the presence of these sporadic $\mathrm{P} / \mathrm{hCNP} 2 \mathrm{hGFP}^{+}$neurons and astrocytes after FACS suggests that $\mathrm{P} / \mathrm{hCNP} 2$-defined progenitors may harbor or retain latent multilineage potential, which may be excercised in the low-density, homogeneous cellular environment of the sorted pool.

\section{DISCUSSION}

These data indicate that the adult human subcortex harbors a population of residual, mitotically competent oligodendrocyte progenitor cells. The cells constitute a discrete population of bipolar blasts, distinct from mature oligodendrocytes. The progenitors are mitotically competent, and as such, distinct from the much larger population of mature, apparently postmitotic oligodendrocytes. These cells were antigenically immature $\left(\mathrm{A} 2 \mathrm{~B} 5^{+} /\right.$ $\left.\mathrm{O}^{-}\right)$when isolated but matured $\left(\mathrm{O}^{+} / \mathrm{O} 1^{+}\right)$over several weeks 

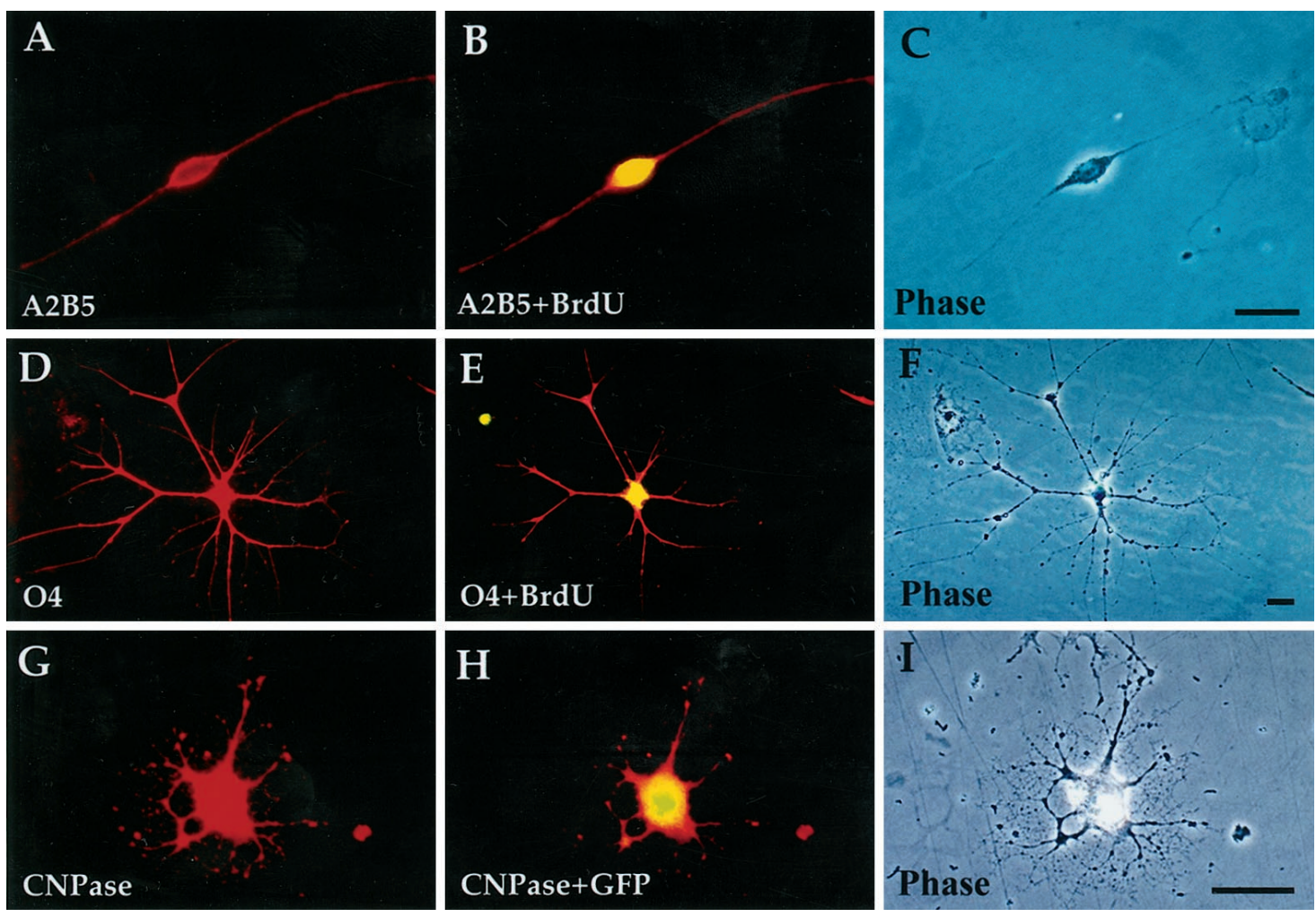

Figure 6. P/hCNP2:hGFP-sorted cells divide and express oligodendrocytic markers. $A-C$, A bipolar A2B5 ${ }^{+} / \mathrm{BrdU}^{+}$cell 48 hr after FACS. $D-F$, Within 3 weeks, the bipolar cells matured into fibrous, $\mathrm{O}^{+}{ }^{+}$cells. These cells often incorporated BrdU, indicating their in vitro origin from replicating A2B5 ${ }^{+}$ cells. $G-I$, A multipolar oligodendrocyte expressing CNP, still expressing GFP 3 weeks after FACS. Scale bar, $20 \mu \mathrm{m}$.

in culture. Cell-specific targeted reporting, achieved by transfecting the overall white matter pool with plasmids of GFP placed under the control of the early promoter for oligodendrocytic CNP, allowed the live-cell identification of these progenitor cells. This in turn provided a means for their isolation and purification by fluorescence-activated cell sorting based on $\mathrm{P} / \mathrm{hCNP} 2$-driven GFP expression.

\section{The nature of the adult white matter progenitor pool}

$\mathrm{P} / \mathrm{hCNP} 2$-defined oligodendrocytic progenitors were not rare. By our sorting criteria, they constituted as many as $4 \%$ of cells in the adult human white matter. This figure is marginally greater than previous estimates based on histological identification of PDGF $\alpha$ R expression (Scolding et al., 1998). However, our experiments may have selected for smaller, less fibrous cells, which might be the most capable of surviving tissue dissociation and sorting. Such a bias might have tended to overestimate the incidence of competent progenitor cells in the parenchymal dissociates, so that $4 \%$ should be viewed as an upper limit estimate of the incidence of progenitor cells in human subcortical white matter. Nonetheless, the relative abundance and ubiquity of these cells suggest that they may play an important role in the maintenance and function of the normal adult white matter. In rats, a substantial proportion of the white matter cell population is cycling at any one time (Gensert and Goldman, 1996). These cells may be recruited to oligoneogenesis in the event of demyelinating injury (Gensert and Goldman, 1997), and they may be induced to divide in vitro by combinations of factors to which they are responsive in development (McMorris and McKinnon, 1996; Shi et al., 1998). Salient differences have been noted in the factor responsiveness of oligodendrocyte progenitors in adult rats and humans, so that the implications of studies on rodent-derived OPs for human oligodendrocyte progenitor biology remain unclear (Scolding, 1998). Nonetheless, the presence of such a large pool of mitotically competent progenitors in humans suggests that some degree of oligodendrocytic turnover may be occurring in the subcortical white matter. This in turn suggests the possible replacement of damaged or dysfunctional postmitotic oligodendrocytes by progenitor-derived recruits. Recent advances in our understanding of both the humoral and contact-mediated control of oligodendrocyte progenitor expansion in rodents (Shi et al., 1998; Wang et al., 1998c) argue that these endogenous progenitors will prove attractive targets for exogenous activation.

\section{Ontogeny and lineage of parenchymal oligodendrocytic precursors}

Neural precursor cells are widespread in the subependymal zone of the forebrain ventricular lining (Goldman and Nottebohm, 1983; Lois and Alvarez-Buylla, 1993; Luskin, 1993; Morshead et al., 1994; Kirschenbaum et al., 1994; Kirschenbaum and Goldman, 1995; Pincus et al., 1998) (for review, see Goldman, 1998; Goldman and Luskin, 1998). At least some of these cells may manifest glial antigenicity in situ (Doetsch et al., 1999). Whether the P/hCNP2:hGFP-defined subcortical precursors described here are coderived with the subependymal progenitor pool is unknown. It is also unclear whether the $\mathrm{P} / \mathrm{hCNP} 2$-defined precursors constitute committed oligodendrocyte precursors or whether they are more intrinsically pluripotential and generate given lineages as a function of the environment to which they are exposed. The latter possibility is suggested by the small proportion of $\mathrm{P} / \mathrm{hCNP}: \mathrm{hGFP}^{+}$cells that were found to be $\mathrm{GFAP}^{+}$ 

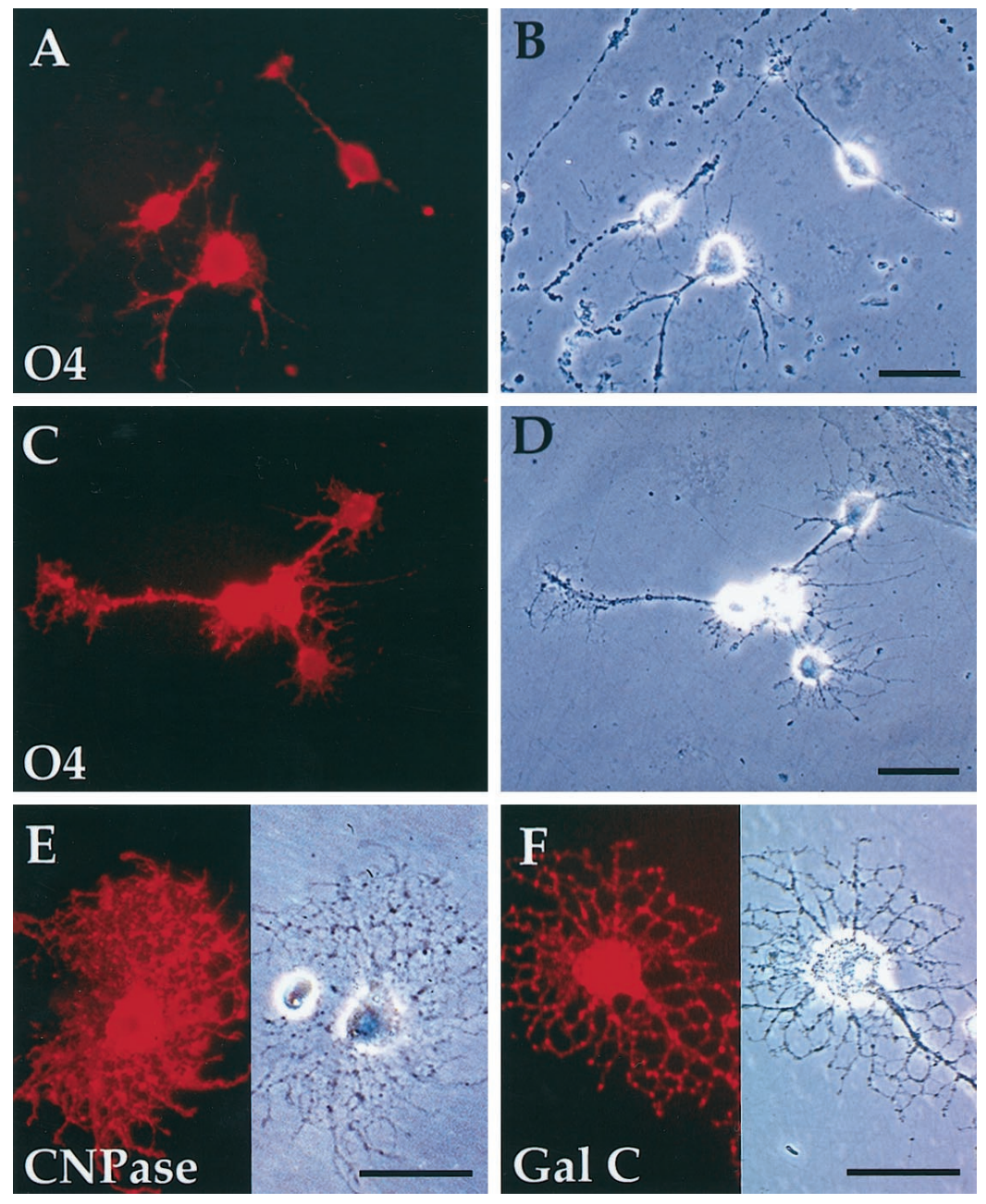

Figure 7. FACS-sorted $\mathrm{P} / \mathrm{hCNP}$ : $\mathrm{hGFP}^{+}$cells mature primarily as oligodendrocytes. $A, B, \mathrm{P} / \mathrm{hCNP} 2$ :hGFP-sorted cells express $\mathrm{O} 4$ (red) and begin process elaboration within $4 \mathrm{~d}$ after FACS. $C, D$, By 2 weeks after FACS, these cells generally develop multipolar morphologies. Red, O4immunoreactive cells. $E, F$, Progenitor derived-cells matured further over the following weeks, developing oligodendrocytic morphologies and both CNP protein $(E)$ and galactocerebroside $(F)$ expression by 4 weeks in vitro. Scale bar, $30 \mu \mathrm{m}$. astrocytes upon immunostaining; many of these never developed expression of any oligodendrocytic marker and appeared instead to be astrocytes. This suggests that the $\mathrm{P} / \mathrm{hCNP} 2$-defined progenitor pool may constitute a bipotential astrocyte-oligodendrocyte progenitor, which may yield primarily oligodendrocytic progeny by virtue of the culture conditions we used. As such, this cell type may well be analogous to its A2B5-defined counterparts in both the perinatal and adult rat optic nerve (Noble et al., 1992; Butt and Ransom, 1993; Colello et al., 1995; Shi et al., 1998).

\section{White matter oligodendrocyte precursors may constitute a pool of multipotential progenitor cells}

Whether these cells might also be competent to generate neurons remains unclear. No P/hCNP2: $\mathrm{hGFP}^{+}$cells were found to ex-
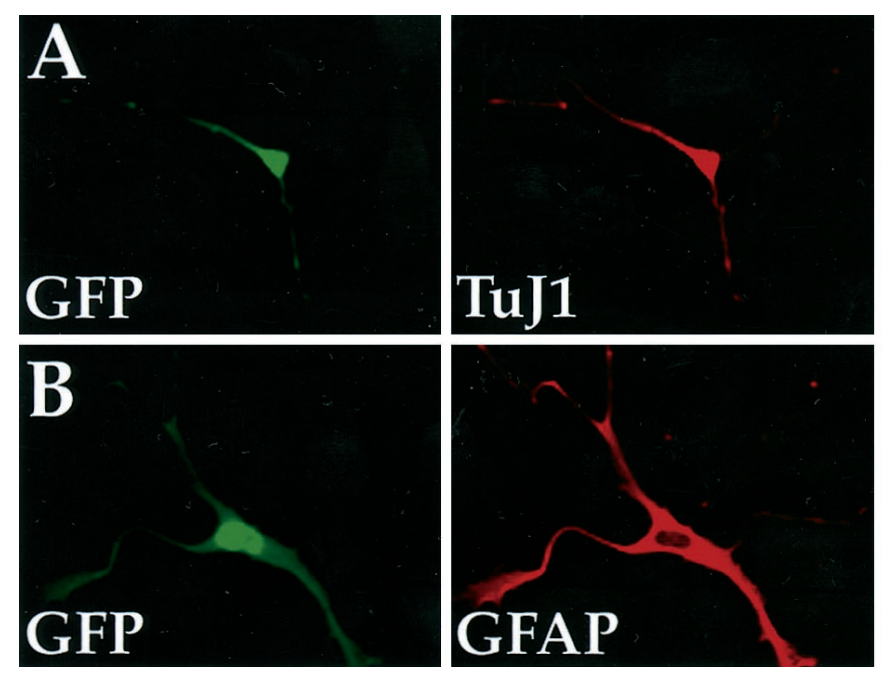
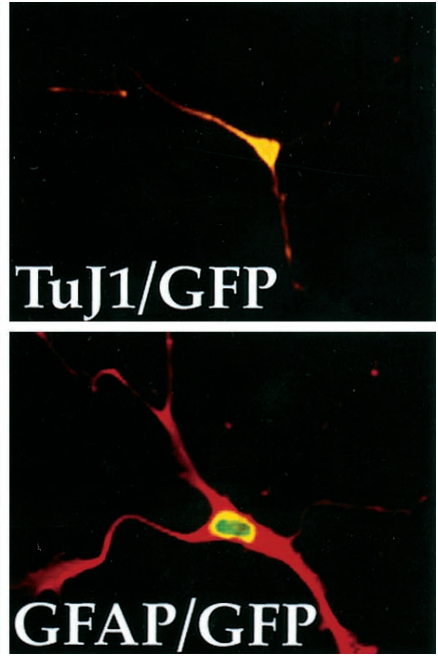

Figure 8. White matter precursor cells may constitute a pool of multipotential progenitors. By 1 week after FACS, some $\mathrm{P} / \mathrm{hCNP}$ :hGFP-sorted cells were noted to mature into either $\mathrm{TuJ} 1^{+}$neurons $(A)$ or $\mathrm{GFAP}^{+}$astrocytes $(B)$. Both the $\mathrm{TuJ}^{+}($red in $A)$ and GFAP ${ }^{+}(\operatorname{red}$ in $B)$ cells were confirmed visually as expressing $\mathrm{P} / \mathrm{hCNP} 2$ :hGFP (green). No such neuronal differentiation of CNP2:hGFPidentified cells was ever noted in unsorted plates, within which these cells generally matured as oligodendrocytes and much less so as astrocytes. This suggests that $\mathrm{P} / \mathrm{hCNP} 2$-defined progenitors may retain some degree of multilineage potential, which may be selectively exercised in the low-density, homogeneous environment of a sorted cell pool in which paracrine influences on differentiation are minimized. 
press neuronal TuJ1 in unsorted white matter cultures, of $>2000$ $\mathrm{hGFP}^{+}$cells studied. Nonetheless, a small number of $\mathrm{TuJ} 1^{+}$cells were noted to develop in $\mathrm{P} / \mathrm{hCNP} 2$ :hGFP-sorted cultures, and these TuJ1-defined neurons were confirmed as P/hCNP2:hGFP ${ }^{+}$ and were not nonfluorescent contaminants of the sorts. Thus, with time in vitro, particularly in the mitogenic FGF2/PDGF/NT3 environment provided here, it remains possible that these cells retain or regain a capacity for multilineage differentiation, as in development (Williams et al., 1991; Davis and Temple, 1994). Importantly, we only noted $\mathrm{P} / \mathrm{hCNP} 2$ :hGFP-defined cells to mature as neurons after high-grade enrichment by sorting. Thus, the multilineage potential of these cells might be preferentially exercised after their isolation from other cell types in low-density culture. As such, the relative fidelity to oligodendrocytic phenotype by P/hCNP2:hGFP-defined cells in the initial white matter dissociates, before FACS, might reflect an initial restriction of progenitor phenotype by paracrine and/or density-dependent influences in vitro. Removal and sorting of these cells to lowdensity, phenotypically homogeneous culture might effectively remove such paracrine restrictions, in essence revealing a multipotential progenitor cell in the adult subcortical parenchyma.

\section{Implantation for the treatment of demyelinating diseases}

The high-yield acquisition of oligodendrocyte progenitor cells from the adult human white matter may allow us to better define those growth and differentiation requirements specific to these cells. The potential use of these cells as substrates for induced remyelination, whether upon endogenous activation or engraftment, suggests therapeutic strategies appropriate to a variety of white matter diseases. These potential therapeutic targets include ischemic demyelination, as in subcortical lacunar infarction and hypertensive leukoencephalopathy, postinflammatory demyelinations, such as radiation necrosis and remitted multiple sclerosis, as well as the degenerative and metabolic leukodystrophies.

Together, these observations suggest that a phenotypically distinct pool of oligodendrocyte progenitor cells persists in relative abundance in the adult human white matter. P/hCNP2:hGFPbased FACS permits their viable harvest in sufficient numbers and purity to enable their potential use in cell-based therapeutic strategies.

\section{REFERENCES}

Armstrong RC, Dorn HH, Kufta CV, Friedman E, Dubois-Dalcq ME (1992) Pre-oligodendrocytes from adult human CNS. J Neurosci 12:1538-1547.

Bansal R, Lemmon V, Gard A, Ranscht B, Pfeiffer S (1989) Multiple and novel specificities of monoclonal antibodies $\mathrm{O} 1, \mathrm{O} 4$, and $\mathrm{R}-\mathrm{mAb}$, in the analysis of oligodendrocyte development. J Neurosci Res 24:548-557.

Bernier L, Alvarez F, Norgard E, Schembri J, Sabatini D, Colman D (1987) Molecular cloning of a $2^{\prime}, 3^{\prime}$-cyclic nucleotide phosphodiesterase. J Neurosci 7:2703-2710.

Blakemore W, Franklin R, Noble M (1996) Glial cell transplantation and the repair of demyelinating lesions. In: Glial cell development: basic principles and clinical relevance (Jessen $\mathrm{K}$, Richardson W, eds), pp 209-220. Oxford: BIOS Scientific.

Butt AM, Ransom BR (1993) Morphology of astrocytes and oligodendrocytes during development in the intact rat optic nerve. J Comp Neurol 338:141-158.

Chalfie M, Tu Y, Euskirchen G, Ward W, Prasher D (1994) Green fluorescent protein as a marker for gene expression. Science 263:802-805.

Chandross K, Cohen R, Paras P, Gravel M, Braun P, Hudson L (1999) Identification and characterization of early glial progenitors using a transgenic selection strategy. J Neurosci 19:759-774.

Colello RJ, Devey LR, Imperato E, Pott U (1995) The chronology of oligodendrocyte differentiation in the rat optic nerve: evidence for a signaling step initiating myelination in the CNS. J Neurosci 15:7665-7672.

Davis AA, Temple S (1994) A self-renewing multipotential stem cell in embryonic rat cerebral cortex. Nature 372:263-266.

Doetsch F, Caille I, Lim D, Garcia-Verdugo S, Alvarez-Buylla A (1999) Subventricular zone astrocytes are neural stem cells in the adult mammalian brain. Cell 97:703-716.

Douglas A, Thompson R (1993) Structure of the myelin membrane enzyme CNP: evidence for two human mRNAs. Biochem Soc Trans 21:295-297.

Douglas A, Fox M, Abbot C, Hinks L, Sharpe G, Povey S, Thompson R (1992) Structure and chromosomal localization of the human $2^{\prime}-3^{\prime}-$ cyclic nucleotide $3^{\prime}$-phosphodiesterase gene. Ann Hum Genet 56:243-254.

Gensert JM, Goldman JE (1996) In vivo characterization of endogenous proliferating cells in adult rat subcortical white matter. Glia 17:39-51.

Gensert JM, Goldman JE (1997) Endogenous progenitors remyelinate demyelinated axons in the adult CNS. Neuron 19:197-203.

Gloster A, Wu W, Speelman A, Weiss S, Causing C, Pozniak C, Reynolds B, Chang E, Toma J, Miller F (1994) The T $\alpha 1 \alpha$-tubulin promoter specifies gene expression as a function of neuronal growth and regeneration in transgenic mice. J Neurosci 14:7319-7330.

Gogate N, Verma L, Zhou JM, Milward E, Rusten R, O'Connor M, Kufta C, Kim J, Hudson L, Dubois-Dalcq M (1994) Plasticity in the adult human oligodendrocyte lineage. J Neurosci 14:4571-4587.

Goldman SA (1998) Adult neurogenesis: from canaries to the clinic. J Neurobiol 36:267-286.

Goldman SA, Luskin M (1998) Strategies utilized by migrating neurons of the postnatal vertebrate forebrain. Trends Neurosci 21:107-114.

Goldman SA, Nottebohm F (1983) Neuronal production, migration, and differentiation in a vocal control nucleus of the adult female canary brain. Proc Natl Acad Sci USA 80:2390-2394.

Goldman SA, Zaremba A, Niedzwiecki D (1992) In vitro neurogenesis by neuronal precursor cells derived from the adult songbird brain. J Neurosci 12:2532-2541.

Goldman SA, Nedergaard M, Crystal R, Fraser R, Goodman R, Harrison C, Keyoung HM, Leventhal C, Pincus D, Shahar A, Wang S (1997) Neural precursors and neuronal production in the adult mammalian forebrain. Ann NY Acad Sci 835:30-45.

Gravel M, Peterson J, Yong V, Kottis V, Trapp B, Braun P (1996) Overexpression of $2^{\prime}, 3^{\prime}$-cyclic nucleotide $3^{\prime}$-phosphodiesterase in transgenic mice alters oligodendrocyte development and produces aberrant myelination. Mol Cell Neurosci 7:453-466.

Gravel M, DiPolo A, Valera P, Braun P (1998) Four-kilobase sequence of the mouse CNP gene directs spatial and temporal expression of lacZ in transgenic mice. J Neurosci Res 53:393-404.

Grever W, Weidenheim K, Tricoche M, Raghbaum W, Lyman W (1997) Oligodendrocyte gene expression in the human fetal spinal cord during the second trimester of gestation. J Neurosci Res 47:332-340.

Kirschenbaum B, Goldman SA (1995) Brain-derived neurotrophic factor promotes the survival of neurons arising from the adult rat forebrain subependymal zone. Proc Natl Acad Sci USA 92:210-214.

Kirschenbaum B, Nedergaard M, Preuss A, Barami K, Fraser RA, Goldman SA (1994) In vitro neuronal production and differentiation by precursor cells derived from the adult human forebrain. Cereb Cortex 4:576-589.

Leventhal C, Rafii S, Rafii D, Shahar A, Goldman S (1999) Endothelial trophic support of neuronal production and recruitment by the adult mammalian subependyma. Mol Cell Neurosci 13:450-464.

Levy J, Muldoon R, Zolotukhin S, Link C (1996) Retroviral transfer and expression of a humanized, red-shifted green fluorescent protein gene into human tumor cells. Nat Biotechnol 14:610-614.

Lois C, Alvarez-Buylla A (1993) Proliferating subventricular zone cells in the adult mammalian forebrain can differentiate into neurons and glia. Proc Natl Acad Sci 90:2074-2077.

Luskin M, Zigova T, Soteres B, Stewart R (1997) Neuronal progenitor cells derived from the anterior subventricular zone of the neonatal rat forebrain continue to proliferate in vitro and express neuronal phenotype. Mol Cell Neurosci 8:351-366.

Luskin MB (1993) Restricted proliferation and migration of postnatally generated neurons derived from the forebrain subventricular zone. Neuron 11:173-189.

McMorris F, McKinnon R (1996) Regulation of oligodendrocyte devel- 
opment and CNS myelination by growth factors: prospects for therapy of demyelinating disease. Brain Pathol 6:313-329.

Menezes JR, Luskin MB (1994) Expression of neuron-specific tubulin defines a novel population in the proliferative layers of the developing telencephalon. J Neurosci 14:5399-5416.

Monoh K, Kurihara T, Takahashi Y, Ichikawa T, Kumanishi T, Hayashi S, Minoshima S, Shimizu N (1993) Structure, expression and chromosomal localization of the gene encoding human $2^{\prime}-3^{\prime}$-cyclic nucleotide 3'-phosphodiesterase. Gene 129:297-301.

Morshead CM, Reynolds BA, Craig CG, McBurney MW, Staines WA, Morassutti D, Weiss S, van der Kooy D (1994) Neural stem cells in the adult mammalian forebrain: a relatively quiescent subpopulation of subependymal cells. Neuron 13:1071-1082.

Noble M, Wren D, Wolswijk G (1992) The O-2A(adult) progenitor cell: a glial stem cell of the adult central nervous system. Semin Cell Biol $3: 413-422$.

O’Neill R, Minuk J, Cox M, Braun P, Gravel M (1997) CNP2 mRNA directs synthesis of both CNP1 and CNP2 polypeptides. J Neurosci Res 50:248-257.

Peyron F, Timsit S, Thomas J, Kagawa T, Ikenaka K, Zalc B (1997) In situ expression of PLP/DM20, MBP and CNP during embryonic and postnatal development of the jimpy mutant and of transgenic mice overexpressing PLP. J Neurosci Res 50:190-201.

Pincus D, Keyoung H, Harrison-Restelli C, Sakakibara S, Okano H, Goodman R, Fraser R, Edgar M, Nedergaard M, Goldman SA (1998) FGF2/BDNF-associated maturation of new neurons generated from adult human subependymal cells. Ann Neurol 43:576-585.

Rafii S, Shapiro R, Pettengell B, Ferris B, Nachman R, Moore M, Asch A (1995) Human bone marrow microvascular endothelial cells support long-term proliferation and differentiation of myeloid and megakaryocytic progenitors. Blood 86:3353-3363.

Scherer S, Braun P, Grinspan J, Collarini E, Wang D, Kamholz J (1994) Differential regulation of the $2^{\prime}, 3^{\prime}$-cyclic nucleotide $3^{\prime}$ phosphodiesterase gene during oligodendrocyte development. Neuron 12:1363-1375.

Scolding N (1997) Strategies for repair and remyelination in demyelinating diseases. Curr Opin Neurol 10:193-200.
Scolding N (1998) Glial precursor cells in the adult human brain. The Neuroscientist 4:264-272.

Scolding NJ, Rayner PJ, Sussman J, Shaw C, Compston DA (1995) A proliferative adult human oligodendrocyte progenitor. NeuroReport 6:441-445.

Scolding N, Franklin R, Stevens S, Heldin C, Compston A, Newcombe J (1998) Oligodendrocyte progenitors are present in the normal adult human CNS and in the lesions of multiple sclerosis. Brain 121:2221-2228.

Shi J, Marinovitch A, Barres B (1998) Purification and characterization of adult oligodendrocyte precursor cells from the rat optic nerve. J Neurosci 18:4627-4636.

Tsukada Y, Kurihara T (1992) Cyclic nucleotide phosphodiesterase: Molecular characterization and possible functional significance. In: Myelin: biology and chemistry (Martenson R, ed), pp 449-480. Boca Raton, FL: CRC.

Vogel U, Reynolds R, Thompson R, Wilkin G (1988) Expression of the CNPase gene and immunoreactive protein in oligodendrocytes as revealed by in situ hybridization and immunofluorescence. Glia 1:184-191.

Wang S, Wu H, Jiang W, Isdell F, Delohery T, Goldman S (1998a) Identification and enrichment of forebrain neuronal precursor cells by fluorescence-activated sorting of ventricular zone cells transfected with GFP regulated by the T $\alpha 1$ tubulin promoter. Nat Biotechnol 16:196-201.

Wang S, Maiyer A, Harrison C, Fraser R, Gravel M, Braun P, Goldman SA (1998b) Isolation and purification of oligodendrocyte progenitor cells from the adult human subcortex. Ann Neurol 44:438.

Wang S, Sdrulla AD, diSibio G, Bush G, Nofziger D, Hicks C, Weinmaster G, Barres BA (1998c) Notch receptor activation inhibits oligodendrocyte differentiation. Neuron 21:63-75.

Williams BP, Read J, Price J (1991) The generation of neurons and oligodendrocytes from a common precursor cell. Neuron 7:685-693.

Yu W-P, Collarini E, Pringle N, Richardson W (1994) Embryonic expression of myelin genes: evidence for a focal source of oligodendrocyte precursors in the ventricular zone of the neural tube. Neuron 12:13531362. 